\title{
Association between domestic violence and oral health conditions among adolescents
}

\author{
Associação entre violência doméstica e condições de saúdle bucal entre adolescentes \\ Asociación entre la violencia doméstica y las condiciones de salud bucal entre los adolescentes
}

Received: 08/05/2021 | Reviewed: 08/10/2021 | Accept: 08/15/2021 | Published: 08/17/2021

Beatriz de Araújo Gusmão

ORCID: https://orcid.org/0000-0002-2182-9649

University de Pernambuco, Brazil

E-mail: beatriz.gusmao@upe.br

Laura Arruda do Nascimento

ORCID: https://orcid.org/0000-0002-9087-2157

University of Pernambuco, Brazil

E-mail: laura.arruda@upe.br

Michele Gomes do Nascimento

ORCID: https://orcid.org/0000-0003-2175-7080

University of Pernambuco, Brazil

E-mail: michelepmpe@yahoo.com.br

Fabiana Godoy

ORCID: https://orcid.org/0000-0002-1946-9605

University of Pernambuco, Brazil

E-mail: fabiana.godoy10@upe.br

Carolina da Franca

ORCID: https://orcid.org/0000-0002-7365-2806

University of Pernambuco, Brazil

E-mail: carolina.franca@upe.br

Valdenice Menezes

ORCID: https://orcid.org/0000-0003-4183-3239

University of Pernambuco, Brazil

E-mail: valdmenezes@ hotmail.com

Viviane Colares

ORCID: https://orcid.org/0000-0003-2912-2100

University of Pernambuco, Brazil

E-mail: viviane.colares@upe.br

\begin{abstract}
This study surveyed the oral health conditions of adolescents aged 15 to 19 years and their association with exposure to domestic violence. The study sample consisted of 333 adolescents enrolled in the State School System in the city of Olinda, PE, Brazil. Sociodemographic data, information on the participant's oral health conditions, and their history of domestic physical violence were collected. The health-related variables analyzed included self-perceived oral health, history of toothache, and the frequency of toothbrushing and visits to the dentist. The data were entered into the Epi data 3.1 and analyzed in the SPSS program 23.0 by Pearson's Chi-square or Fisher's exact tests. There was a significant association of history of toothache and domestic violence with physical aggression from the mother $(\mathrm{P}=$ 0.001 ; $\mathrm{OR}=2.39)$, a relative $(\mathrm{P}=0.001 ; \mathrm{OR}=2.41)$ and any family member and/or with witnessing violent acts between the parents $(\mathrm{P}=0.011$; $\mathrm{OR}=1.88)$. However, no association between physical violence and self-perceived oral health or the frequency of visits to the dentist was observed. To conclude, our findings indicate that the oral health conditions of adolescents may be directly associated with domestic violence.
\end{abstract}

Keywords: Adolescent; Child abuse; Domestic violence; Pain; Oral health.

\section{Resumo}

Esse estudo teve como objetivo avaliar as condições de saúde bucal de adolescentes entre 15 a 19 anos e suas associações com exposição à violência doméstica. A amostra foi formada por 333 adolescentes, matriculados na rede estadual de ensino do município de Olinda. Foram coletados dados sociodemográficos, de condições de saúde bucal e de violência física familiar. Com relação à saúde bucal foram avaliados: autopercepção de saúde bucal, histórico de dor de dente, frequência de escovação e visita ao dentista. Os dados foram tabulados no Epi data 3.1 e as análises estatísticas foram feitas através do programa SPSS na versão 23. Foi utilizado o teste Qui-quadrado de Pearson ou o teste Exato de Fisher. Observou-se associação entre dor de dente e violência doméstica: com agressão física pela mãe $(\mathrm{p}=0,001 ; \mathrm{OR}=2,39)$, com agressão por algum membro da família $(\mathrm{p}=0,001 ; \mathrm{OR}=2,41)$ e com agressão por algum membro da família e/ou testemunha de violência entre os pais $(\mathrm{p}=0,011 ; \mathrm{OR}=1,88)$. Entretanto, não se observou associação entre violência física e autopercepção de saúde bucal dos adolescentes ou visita ao dentista. Conclui-se que as condições de saúde bucal de adolescentes podem estar associada à violência doméstica. 
Palavras-chave: Adolescente; Maus-tratos infantis; Violência doméstica; Dor; Saúde bucal.

\section{Resumen}

Este estudio tuvo como objetivo evaluar las condiciones de salud bucal de los adolescentes de entre 15 y 19 años y sus asociaciones con la exposición a la violencia doméstica. La muestra consistió en 333 adolescentes inscritos en el sistema escolar estatal del municipio de Olinda. Se recopilaron datos sociodemográficos, de condiciones de salud bucal y de violencia física familiar. Com respecto a la salud bucal, se evaluaron los siguientes: auto-percepción de la salud bucal, antecedentes de dolor de diente, frecuencia de cepillado y visita al dentista. Los datos fueron tabulados en Epi data 3.1 y los análisis estadísticos se realizaron utilizando el programa SPSS en la versión 23. Se utilizó la prueba chi-cuadrada de Pearson o la prueba exacta del Fisher. Hubo una asociación entre el dolor de muelas y la violencia doméstica: con la agresión física de la madre $(\mathrm{p}=0.001 ; \mathrm{OR}=2.39)$, con agresión de un miembro de la familia $(\mathrm{p}=0.001 ; \mathrm{OR}=2.41)$ y con agresión por parte de algún miembro de la familia y/o testigo de violencia entre padres $(\mathrm{p}=0.011 ; \mathrm{OR}=1.88)$. Sin embargo, no huvo asociación entre la violencia física y la auto-percepción de la salud bucal de los adolescentes o la visita al dentista. Se concluye que las condiciones de salud bucal de los adolescentes pueden estar asociadas con la violencia doméstica.

Palabras clave: Adolescente; Abuso infantil; Violencia doméstica; Dolor; Salud bucal.

\section{Introduction}

Domestic violence is considered a serious public health issue, with high incidence rates in Brazilian cities (Souza et al., 2017). It is considered a multi-causal phenomenon, and may be related to family breakdown, lack of assistance to education, health and social interaction (Costa et al., 2020). According to the World Health Organization (WHO), child abuse in the domestic environment may range from neglect to severe cases involving physical force and sexual abuse (Krug et al., 2002).

Children and adolescents have less autonomy and are directly dependent on their guardian(s), which renders them more susceptible to suffer from this type of violence (Serafim et al., 2016). After the onset of the COVID-19 pandemic, the compulsory social distancing and the consequent suspension of face-to-face classes, young people were further exposed to domestic violence with direct effects on their physical health (Cluver et al., 2020). The home may often not be the safest place for those who have already experienced this type of aggression (Trajano et al. 2021), as without the social support network it is easier to keep the secret of violence at home (Fundo das Nações Unidas para a Infância [UNICEF], 2020)

The Child and Adolescent Statute (ECA, in Portuguese) was created in Brazil to overcome the imbalance inherent in such a minor-family member relationship. This statute establishes guidelines for protecting minors, such as the mandatory notification by health and education professionals in suspected or confirmed cases of child abuse (Moreira et al., 2014). However, even in the face of legislation requiring denunciation, it is still an invisible tool in the routine of these professionals (Silva et al., 2021).

The oral health conditions of adolescents may be affected by violent acts suffered or witnessed within their households. Studies have shown that caries experience is strongly associated with risk factors suggestive of neglect (Lourenço et al., 2013) and that abused children are often more neglected by their caregivers both in terms of personal hygiene and access to healthcare treatments (Montecchi et al., 2009).

Physical violence has also been associated with the occurrence of oral issues since the head and neck region is the most affected site (Souza et al., 2017), accounting for nearly 65\% of the cases of domestic violence among adolescents (Matos et al., 2020).

Despite this, child abuse cases and incidents have been critically underreported in Brazil for many reasons, among which are the lack of expertise of dentists in identifying warning signs of domestic abuse and because such a topic has been unsatisfactorily addressed in undergraduate dental courses (Moreira et al., 2015). A previous study surveyed a total of 80 dentists in the city of São Paulo about any previous dental care appointment delivered to patients allegedly suffering from domestic violence. Most of the participating dentists reported never having noticed any warning signs of abuse (Carvalho et al., 
2013). This suggests that the association between domestic violence and one's oral health condition remains unexplored in the daily routine of dental professionals and the scientific literature. Thus, this study aimed to survey the oral health conditions of adolescents and determine their association with exposure to domestic violence.

\section{Methodology}

\subsection{Study Design}

This was a cross-sectional, descriptive, analytical, school-based study (Pereira et al., 2018) with an exploratory analysis that was part of a larger project entitled "Oral health and health risk behavior that can be modified in adolescence monitor to prevent". The data were collected between March and August 2018.

\subsection{Target Population}

The study population consisted of school adolescents enrolled in the State School System in the city of Olinda, PE, Brazil, in the age group 15 to 19 years, of both sexes.

\subsection{Sample Size}

The sample size of this exploratory study corresponded to approximately $20 \%$ of the number of adolescents who participated in the clinical examination $(n=1,742)$ in the main (larger) project, totaling 333 students.

\subsection{Sample Selection And Eligibility Criteria}

High school adolescents, of both sexes, aged 15 to 19 years, regularly enrolled in the state public high school in the city of Olinda, Pernambuco, and who participated in all stages of data collection (questionnaire filling and oral examination) were considered eligible. Students with systemic health issues, any disability or dysfunction that prevented them from selffilling the questionnaire, and those whose questionnaires had $20 \%$ or more unanswered questions were excluded from the analysis.

\subsection{Research Instruments}

To assess the variables related to exposure to domestic violence, the Youth Risk Behavior Survey (YRBS) questionnaire was applied. This questionnaire was developed by the WHO with technical and financial assistance from the Center for Disease Control and Prevention and has already been applied in samples from approximately 100 developing countries, including Brazilian adolescents (Guedes et al., 2010). Data related to the adolescents' health status were collected, with additional questions from the instrument used in the National Schoolchildren Health Survey (PeNSE, in Portuguese), which was conducted by the Brazilian Institute of Geography and Statistics (IBGE). Some questions from the Health Behavior in School-aged Children (HBSC) tool developed by the WHO were also used to obtain information on the participants' wellbeing and self-perceived health.

To investigate their exposure to domestic violence, participating adolescents were asked whether they had suffered physical aggression from any relative, father and/or mother and, if so, the frequency of the incident, and whether they had witnessed any violent act among the adults with whom they lived. Questions addressing their oral health condition were also included, namely: history of toothache in the previous 6 months, the frequency of visits to the dentist in the previous 12 months, the frequency of toothbrushing in a period of 30 days, and how they perceived their oral health. 


\subsection{Data Analysis}

The data were entered into the Epi data 3.1 program and analyzed statistically in the Statistical Package for the Social Sciences program (IMB / SPSS), version 23.0. Pearson's Chi-square test was used to check for a significant association between two categorical variables, or Fisher's exact test when the Chi-square test was not applicable. The strength of the association between the adolescents' oral health conditions and their degree of exposure to domestic physical violence was determined by the Odds Ratio (OR) and confidence intervals. A 5\% significance level and a 95\% confidence interval were considered in all statistical tests.

\subsection{Ethical Considerations}

This study was previously approved by the Human Research Ethics Committee at the Federal University of Pernambuco, under protocol CAAE 76609817.1.0000.5207, following Resolution No. 196/96 of the National Health Council.

\section{Results}

The final sample of 333 adolescents had a homogenous sex distribution, with males being slightly more representative $(54.1 \%)$. The groups were also homogenous regarding age, with a slight predominance of adolescents aged 15 and 16 years (55.9\%). Most of the participants (38.1\%) reported their family income to be less than or equal to one minimum wage at the time of data collection (BRL 965.00). Less than half of the participants stated that the family was assisted by the Bolsa Família social program (44.1\%). A significant number of students lived with both parents $(64.9 \%)$ as compared to those living only with their father or mother (19.8\%), or any relative (15.3\%). Most adolescents reported that their mother's schooling was equal to or greater than 8 years $(58.6 \%)$ and self-rated their skin color as brown $(49.2 \%)$, followed by black (18.3\%) and white $(15 \%)$.

The participants' oral health conditions and related behaviors were surveyed, and the results indicated a homogeneous distribution between positive (50.2\%) and negative (49.8\%) self-perceived oral health. Nearly a quarter of the students $(26.7 \%)$ reported an episode of toothache in the previous 6 months and most of them had not visited the dentist in the previous year (47.7\%). In addition, most respondents reported a satisfactory frequency of toothbrushing (93.4\%).

The degree of exposure to domestic violence most reported by the adolescents was witnessing physical violence among adult family members (44.7\%), followed by having suffered physical aggression from a relative (32.3\%). Concerning the violence committed by their parents, the physical aggression perpetrated by the mother (27.0\%) was more frequent than that committed by the father (12.9\%).

Tables 1 and 2 show that self-perceived oral health and the frequency of visits to the dentist in the previous 12 months were not associated with any type of exposure to domestic violence. 
Research, Society and Development, v. 10, n. 10, e524101019132, 2021

(CC BY 4.0) | ISSN 2525-3409 | DOI: http://dx.doi.org/10.33448/rsd-v10i10.19132

Table 1 - Self-perceived oral health among adolescents according to their exposure to domestic violence.

\begin{tabular}{|c|c|c|c|c|c|c|c|c|}
\hline \multirow{3}{*}{$\begin{array}{l}\text { Suffered and/or witnessed } \\
\text { domestic physical violence }\end{array}$} & \multicolumn{4}{|c|}{ Self-perceived oral health } & & & \multirow{3}{*}{$P$-value } & \multirow{3}{*}{ OR $(95 \% \mathrm{CI})$} \\
\hline & \multicolumn{2}{|c|}{ Negative } & \multicolumn{2}{|c|}{ Positive } & \multicolumn{2}{|c|}{ Total } & & \\
\hline & $n$ & $\%$ & $n$ & $\%$ & $n$ & $\%$ & & \\
\hline Total group & 166 & 49.8 & 167 & 50.2 & 100.0 & 100.0 & & \\
\hline From the mother & & & & & & & $\mathrm{p}^{(1)}=0.973$ & \\
\hline Yes & 45 & 50.0 & 45 & 50.0 & 90 & 100.0 & & 1.01 (0.62 to 1.64$)$ \\
\hline No & 121 & 49.8 & 122 & 50.2 & 243 & 100.0 & & 1.00 \\
\hline \multicolumn{9}{|l|}{ From the father } \\
\hline Yes & 23 & 53.5 & 20 & 46.5 & 43 & 100.0 & $\mathrm{p}^{(1)}=0.609$ & 1.18 (0.62 to 2.25$)$ \\
\hline No & 143 & 49.3 & 147 & 50.7 & 290 & 100.0 & & 1.00 \\
\hline \multicolumn{9}{|c|}{$\begin{array}{l}\text { Witnessed domestic violence between } \\
\text { adult relatives }\end{array}$} \\
\hline Yes & 53 & 57.6 & 39 & 42.4 & 92 & 100.0 & $\mathrm{p}^{(1)}=0.080$ & 1.54 (0.95 to 2.50$)$ \\
\hline No & 113 & 46.9 & 128 & 53.1 & 241 & 100.0 & & 1.00 \\
\hline From any relative & & & & & & & $\mathrm{p}^{(1)}=0.970$ & \\
\hline Yes & 54 & 50.0 & 54 & 50.0 & 108 & 100.0 & & 1.01 (0.64 to 1.60$)$ \\
\hline No & 112 & 49.8 & 113 & 50.2 & 225 & 100.0 & & 1.00 \\
\hline \multicolumn{9}{|c|}{$\begin{array}{l}\text { Suffered domestic violence from any } \\
\text { relative and/or witnessed it }\end{array}$} \\
\hline & & & & & & & $\mathrm{p}^{(1)}=0.298$ & \\
\hline Yes & 79 & 53.0 & 70 & 47.0 & 149 & 100.0 & & $1.26(0.82$ to 1.94$)$ \\
\hline No & 87 & 47.3 & 97 & 52.7 & 184 & 100.0 & & 1.00 \\
\hline
\end{tabular}

(1) Pearson's Chi-square test. Source: Authors. 
Table 2 - The frequency of visits of adolescents to the dentist according to their exposure to domestic violence.

\begin{tabular}{|c|c|c|c|c|c|c|c|c|c|}
\hline \multirow{3}{*}{$\begin{array}{l}\text { Suffered and/or witnessed domestic } \\
\text { physical violence }\end{array}$} & \multicolumn{6}{|c|}{ Frequency of visits to the dentist } & & & \multirow{3}{*}{$P$-value } \\
\hline & \multicolumn{2}{|c|}{ Never } & \multicolumn{2}{|c|}{ Once } & \multicolumn{2}{|c|}{$\begin{array}{l}\text { Twice or } \\
\text { more }\end{array}$} & \multicolumn{2}{|c|}{ Total } & \\
\hline & $n$ & $\%$ & $n$ & $\%$ & $n$ & $\%$ & $n$ & $\%$ & \\
\hline Total group & 159 & 47.7 & 69 & 20.7 & 105 & 31.5 & 333 & 100.0 & \\
\hline From the mother & & & & & & & & & $\mathrm{p}^{(1)}=0.555$ \\
\hline Yes & 42 & 46.7 & 16 & 17.8 & 32 & 35.6 & 90 & 100.0 & \\
\hline No & 117 & 48.1 & 53 & 21.8 & 73 & 30.0 & 243 & 100.0 & \\
\hline From the father & & & & & & & & & $\mathrm{p}^{(1)}=0.907$ \\
\hline Yes & 20 & 46.5 & 10 & 23.3 & 13 & 30.2 & 43 & 100.0 & \\
\hline No & 139 & 47.9 & 59 & 20.3 & 92 & 31.7 & 290 & 100.0 & \\
\hline $\begin{array}{l}\text { Witnessed domestic violence betw } \\
\text { adult relatives }\end{array}$ & & & & & & & & & \\
\hline Yes & 40 & 43.5 & 17 & 18.5 & 35 & 38.0 & 92 & 100.0 & $\mathrm{p}^{(1)}=0.286$ \\
\hline No & 119 & 49.4 & 52 & 21.6 & 70 & 29.0 & 241 & 100.0 & \\
\hline From any relative & & & & & & & & & \\
\hline Yes & 51 & 47.2 & 21 & 19.4 & 36 & 33.3 & 108 & 100.0 & \\
\hline No & 108 & 48.0 & 48 & 21.3 & 69 & 30.7 & 225 & 100.0 & $\mathrm{p}^{(1)}=0.861$ \\
\hline $\begin{array}{l}\text { Suffered domestic violence from } \\
\text { relative and/or witnessed it }\end{array}$ & & & & & & & & & \\
\hline Yes & 69 & 46.3 & 28 & 18.8 & 52 & 34.9 & 149 & 100.0 & $\mathrm{p}^{(1)}=0.456$ \\
\hline No & 90 & 48.9 & 41 & 22.3 & 53 & 28.8 & 184 & 100.0 & \\
\hline
\end{tabular}

(1) Pearson's Chi-square test. Source: Authors.

In contrast, the Table 3 show that a history of toothache was significantly associated with domestic violence committed by the adolescent's mother and relatives and/or witnessing violent acts between family members. 
Table 3 - History of toothache among adolescents according to their exposure to domestic violence.

\begin{tabular}{|c|c|c|c|c|c|c|c|c|}
\hline \multirow{3}{*}{$\begin{array}{l}\text { Suffered and/or witnessed } \\
\text { domestic physical violence }\end{array}$} & \multicolumn{4}{|c|}{ History of toothache } & & & \multirow{3}{*}{$P$-value } & \multirow{3}{*}{ OR $(95 \% \mathrm{CI})$} \\
\hline & \multicolumn{2}{|c|}{ Yes } & \multicolumn{2}{|c|}{ No } & \multicolumn{2}{|c|}{ Total } & & \\
\hline & $n$ & $\%$ & $n$ & $\%$ & $n$ & $\%$ & & \\
\hline Total group & 89 & 26.7 & 244 & 73.3 & 333 & 100.0 & & \\
\hline From the mother & & & & & & & $\mathrm{p}^{(1)}=0.001^{*}$ & \\
\hline Yes & 36 & 40.0 & 54 & 60.0 & 90 & 100.0 & & 2.39 (1.42 to 4.02$)$ \\
\hline No & 53 & 21.8 & 190 & 78.2 & 243 & 100.0 & & 1.00 \\
\hline From the father & & & & & & & $\mathrm{p}^{(1)}=0.096$ & \\
\hline Yes & 16 & 37.2 & 27 & 62.8 & 43 & 100.0 & & $1.76(0.90$ to 3.45$)$ \\
\hline No & 73 & 25.2 & 217 & 74.8 & 290 & 100.0 & & 1.00 \\
\hline \multicolumn{9}{|c|}{$\begin{array}{l}\text { Witnessed domestic violence between } \\
\text { adult relatives }\end{array}$} \\
\hline & & & & & & & $\mathrm{p}^{(1)}=0.345$ & \\
\hline Yes & 28 & 30.4 & 64 & 69.6 & 92 & 100.0 & & $1.29(0.76$ to 2.19$)$ \\
\hline No & 61 & 25.3 & 180 & 74.7 & 241 & 100.0 & & 1.00 \\
\hline From any relative & & & & & & & $\mathrm{p}^{(1)}=0.001^{*}$ & \\
\hline Yes & 42 & 38.9 & 66 & 61.1 & 108 & 100.0 & & 2.41 (1.46 to 3.98$)$ \\
\hline No & 47 & 20.9 & 178 & 79.1 & 225 & 100.0 & & 1.00 \\
\hline \multicolumn{9}{|c|}{$\begin{array}{l}\text { Suffered domestic violence from any } \\
\text { relative and/or witnessed it }\end{array}$} \\
\hline & & & & & & & $\mathrm{p}^{(1)}=0.011^{*}$ & \\
\hline Yes & 50 & 33.6 & 99 & 66.4 & 149 & 100.0 & & 1.88 (1.15 to 3.07$)$ \\
\hline No & 39 & 21.2 & 145 & 78.8 & 184 & 100.0 & & 1.00 \\
\hline
\end{tabular}

(*) Significant association at 5\%. (1) Pearson's Chi-square test. Source: Authors.

\section{Discussion}

This study investigated the oral health conditions and self-perceived oral health of adolescents aged 15 to 19 years and determined their relationship with violence exposure as a risk factor. Additionally, the different types and situations of domestic violence reported by the adolescents were further described.

Our findings indicated that only a history of toothache was associated with maternal physical aggression, physical aggression from a relative, or with having witnessed violence between family members. In a previous study, Lourenço, Salgado, Amaral, Gomes, and Senra (2011) found that the main consequences in the lives of children who witnessed violence between their parents were depressive symptoms and insecurity, in addition to behavioral issues. We reasoned that the occurrence of toothache associated with physical aggression can be caused not only by parental neglect but also by the psychological trauma resulting from this stressful situation, indicating that minors are directly impacted by interparental violence.

A homogeneous distribution between positive and negative self-perceived oral health was observed in our study sample. This is in contrast with the findings of a previous study (Santos et al., 2016) carried out in the municipality of Sobral, 
CE, Brazil, where 482 adolescent and young adults aged 15 to 21 years were interviewed self-rated their oral health mostly as good or excellent (adequate) (74.7\%). Meanwhile, another study (Araújo et al., 2017) showed that most of the 187 adolescents aged 15 to 19 years, living in the municipalities of the Archipelago of Marajó, PA, Brazil, felt dissatisfied with their teeth. Such variability in the findings highlights the subjectivity of self-perception, which may be related to the residence area, living and socioeconomic conditions, and even to the adolescent's emotional background.

While most of the adolescents reported a satisfactory frequency of toothbrushing in our study, the time of brushing should be examined with caution since some Brazilian parents have the habit of giving sweet snacks (Fisberg et al., 2016) to their children in the afternoon, while brushing is often performed after the lunch meal only. This may expose minors to dental caries and can be considered a neglectful act. In addition, the quality of toothbrushing also plays a direct role in the individual's oral health.

Witnessing physical aggression among family members was the most frequent experience of violence reported by the participants, followed by physical aggression from a relative and the mother. Other studies showed that mothers are the main perpetrators of physical violence against children and adolescents. This may be because they are more present physically in the lives of their children, particularly when parents are separated and the mother has the child's custody. According to Nunes and Sales (2016), this situation favors the occurrence of domestic violence incidents.

Due to the high number of cases of domestic violence in Brazil, it was necessary to establish a regulation to reduce and criminalize this type of aggression, known as the Law of Spanking. This law, which was included in the Child and Adolescent Statute in 2014, aims to prohibit the physical punishment of children and adolescents by their guardians, as explained by Pêgo, Silva, and Bastos (2015). However, corporal punishment for educational purposes has been long considered normal by society and even today it remains a common occurrence, as confirmed by our findings. Although this type of violence aims to educate the child, it can otherwise cause several issues, including severe emotional distress (Matos et al., 2020).

The cross-sectional design of our study may be considered a limitation since participants were not monitored over time and therefore other relevant information might be lacking. Moreover, this was an exploratory study with a small sample size as compared to the totality of the adolescent population. Nevertheless, the findings presented herein are substantial and provide strong evidence on the factors associated with domestic violence. This study can also contribute to dental practice by encouraging dentists to detect neglect and exposure to violence in pediatric patients.

Among the variables related to the adolescents' oral health conditions, history of toothache was significantly associated with the violence committed by the mother and some other relatives and with witnessing violence between family members.

\section{Conclusion}

In general, we conclude that there is an association between oral health conditions and exposure to domestic violence among the adolescents surveyed.

Among the variables related to the oral health conditions of adolescents, the report of toothache is significantly associated with violence perpetrated by the mother or by some other family member, as well as in the witnessing of violence among family members.

Even though it is a subject that is increasingly in evidence, it is still little explored in the dental scientific community. Therefore, it is recommended that a greater number of studies with large samples be carried out in order to obtain different reference sources and compare them in different locations, social levels and other variables. Moreover, a study on the subject is 
relevant during and after the pandemic of COVID-19, since several values may have changed during this time in which children and parents were more at home.

\section{Acknowledgments}

This study was partially funded by a scientific training scholarship granted by the National Council for Scientific and Technological Development (CNPq, Brazil).

\section{References}

de Aragão Araújo, M. V., Barriga, A. L. C., Emmi, D. T., Pinheiro, H. H. C., \& Barroso, R. F. F. (2017). Prevalência de cárie dentária, autopercepção e impactos em saúde bucal em adolescentes na ilha do Marajó-Pará. Revista Digital APO, 1(1), 11-17.

Carvalho, L. M. F., Galo, R., \& da Silva, R. H. A. (2013). O cirurgião-dentista frente à violência doméstica: conhecimento dos profissionais em âmbito público e privado. Medicina (Ribeirão Preto), 46(3), 297-304.

Cluver, L., Lachman, J. M., Sherr, L., Wessels, I., Krug, E., Rakotomalala, S., Blight, S., Hillis, S., Bachman, G., Green, O., Butchart, A., Tomlinson, M., Ward, C. L., Doubt, J., \& McDonald, K. (2020). Parenting in a time of COVID-19. The Lancet, 395(10231).

Costa, V. S., \& Aguiar, R. S. (2020). Percepção da equipe multidisciplinar acerca dos cuidados à criança e ao adolescente vítima de violência. Research, Society and Development, 9(4), e161943038-e161943038.

Fisberg, M., Previdelli, A. N., Del'Arco, A. P. W. T., Tosatti, A., \& Nogueira-de-Almeid, C. A. (2016). Hábito alimentar nos lanches intermediários de crianças escolares brasileiras de 7 a 11 anos: estudo em amostra nacional representativa. International Journal of Nutrology, 9(04), $225-236$.

Fundo das Nações Unidas para a Infância. (2020). No dejemos que los niños sean las víctimas ocultas de la pandemia de COVID- 19. https://www.unicef.org/argentina/comunicados-prensa/no-dejemos-ninosvictimas- ocultas-pandemia-covid19.

Guedes, D. P., \& Lopes, C. C. (2010). Validação da versão brasileira do youth risk behavior survey 2007. Revista de Saúde Pública, 44, 840-850.

Krug, E. G., Mercy, J. A., Dahlberg, L. L., \& Zwi, A. B. (2002). The world report on violence and health. The lancet, 360(9339), $1083-1088$.

Lourenço, C. B., de Lima Saintrain, M. V., \& Vieira, A. P. G. F. (2013). Child, neglect and oral health. BMC pediatrics, 13(1), 1-8.

Lourenço, L. M., Salgado, F. S., Amaral, A. C., Gomes, S. F. L., \& Senra, L. X. (2011). O impacto do testemunho da violência interparental em crianças: Uma breve pesquisa bibliométrica e bibliográfica. Gerais: Revista Interinstitucional de Psicologia, 4(1), $104-111$.

Matos, É. M. R., Silva, H. K. C., \& Nascimento, F. S. (2020). A Responsabilidade Civil E Legal Do Cirurgião Dentista Frente A Crianças E Adolescente Que Sofrem Maus-Tratos. Revista Cathedral, 2(3), 84-102.

Montecchi, P. P., Di Trani, M., Bufacchi, C., Montecchi, F., \& Polimeni, A. (2009). The dentist's role in recognizing childhood abuses: study on the dental health of children victims of abuse and witnesses to violence. European journal of paediatric dentistry, 10(4), 185-187.

Moreira, G. A. R., Rolim, A. C. A., Saintrain, M. V. D. L., \& Vieira, L. J. E. D. S. (2015). Atuação do cirurgião-dentista na identificação de maus-tratos contra crianças e adolescentes na atenção primária. Saúde em Debate, 39, 257-267.

Moreira, G. A. R., Vieira, L. J. E. D. S., Deslandes, S. F., Pordeus, M. A. J., Gama, I. D. S., \& Brilhante, A. V. M. (2014). Fatores associados à notificação de maus-tratos em crianças e adolescentes na atenção básica. Ciência \& Saúde Coletiva, 19, 4267-4276.

Nunes, A. J., \& Sales, M. C. V. (2016). Violência contra crianças no cenário brasileiro. Ciencia \& saude coletiva, 21, 871-880.

Pêgo, H. A., Silva, L. L., \& Bastos, C. F. (2015). Lei da Palmada e a violência doméstica contra crianças e adolescentes.

Pereira, A. S., Shitsuka, D. M., Parreira, F. J., \& Shitsuka, R. (2018). Metodologia da pesquisa científica. UFSM. https://repositorio.ufsm. br/bitstream/handle/1/15824/Lic_Computacao_Metodologia-Pesquisa-Cientifica. pdf.

Santos, L. M., Noro, L. R. A., Roncalli, A. G., \& Teixeira, A. K. M. (2016). Autopercepção sobre saúde bucal e sua relação com utilização de serviços e prevalência de dor de dente. Revista Ciência Plural, 2(2), 14-27.

Serafim, A. P. R., Rodrigues, L. G., \& do Prado, M. M. (2016). Maus-tratos infantis: um olhar sobre a omissão de pais na atenção à saúde bucal dos seus filhos. Revista Brasileira de Odontologia Legal, 3(1).

da Silva, A. O., Silva, M. D. C. L. C., de Godoy, A. B., da Silva, L. M. R. C., \& de Holanda Soares, A. L. F. (2021). Violência doméstica: A importância da formação do Cirurgião-Dentista frente a esse agravo. Research, Society and Development, 10(5), e4110514654-e4110514654.

de Souza, C. E., de Moraes Rodrigues, Í. F. M., Zocratto, K. B. F., \& de Oliveira, C. A. S. (2017). Violência infantil e a responsabilidade profissional do cirurgião-dentista-revisão de literatura. Revista Brasileira de Odontologia Legal, 4(1).

Trajano, R. K. N., Lyra, C. V. V., Goes, T. Y., \& Gomes, A. C. A. (2021). Comparativo de casos de violência sexual contra criança e adolescente no período 2018-2020. Research, Society and Development, 10(1), e11710111384-e11710111384. 